Trivent Publishing

(C) The Authors, 2016

Available online at http://trivent-publishing.eu/

Series: Engineering and Industry

Volume: Watershed and River Basin Management

\title{
Integrated Modelling for Basinwide Sustainable Management of Water Quality
}

\author{
A.G. Capodaglio, ${ }^{1}$ G. Tartari, ${ }^{2}$ A. Callegari ${ }^{1}$ \\ ${ }^{1}$ Department of Hydraulic Engineering, University of Pavia, Via Ferrata 1, 27100 Pavia, Italy, capo@ unipv.it \\ ${ }^{2}$ IRSA-CNR, Applied Hydrobiology Laboratory, Brugherio, Milano, Italy
}

\begin{abstract}
This paper illustrates a methodological approach used for the implementation of water quality models, with the aim of defining water quality in a lake's immissary and in the lake itself as a result of all different pollution-generating activities within the basin. A steady-state simulation model (QUAL2E) was adopetd to predict changes in the concentration of in-stream nutrient concentrations in the Lambro River within the Lake Pusiano watershed (Northern Italy). Simulation of local hydrology as a preliminary study was conducted using the HEC-HMS model. In this study, watershed analysis is carried out with the "Soil and Water Assessment Tool" (SWAT) package. This paper describes therefore parts of an integrated hydrologic, catchment and stream nutrient modelling system. The river modelling system is designed to simulate at first, and subsequently to develop sustainable reduction plans of nutrient loads delivered to the lake.
\end{abstract}

\section{Keywords}

Water Quality; Modeling; Geographic Information System; Nutrients; Lake

This is an Open Access article distributed in accordance with the Creative Commons Attribution Non Commercial (CC-BYNC-ND 4.0) license, which permits others to copy or share the article, provided original work is properly cited and that this is not done for commercial purposes. Users may not remix, transform, or build upon the material and may not distribute the modified material (http://creativecommons.org/licenses/by-nc/4.0/) 


\section{Introduction}

The European Union's Water Framework Directive (WFD) mandates requirements of future "good water quality" attainment for all surface waters in Europe, and mandates the completion of river basin plans in all EU Member States. Under a "river basin" approach, efficient solutions must be based on intensive monitoring efforts supplemented by the use of water quality modeling to assess future changes and trends in the quality and quantity of water. As a pilot effort to achieve this task, a water quality monitoring and modeling programme was developed and carried out in the Pusiano Lake basin, Northern Italy (Figure 1), to develop a strategy to improve water quality conditions of the river system and, consequently, of the lake itself in order to enhance its potential uses. This study also constitutes a part of a long-term project concerning integrated water resources management in sub Alpine areas, that is carried out by the Applied Hydrobiology Laboratory of IRSA-CNR (Water Research Institute of the Italian National Research Council), in co-operation with a number of institution and universities: PILE (Pusiano Integrated Lake/Catchment Experiment).

Diffuse pollution, which is the main pollution type influencing this basin, is a complex environmental issue due to the multitude of possible pathways that may influence its surface water system. The only approach that can guarantee an adequate estimate of diffuse pollution loads is a water quality model calibrated with direct instream measures of quality parameters. The complexity of this kind of study, including the analysis and integration of a multitude of natural aspects, therefore, is best accomplished by means of GIS (Geographic Information System)-integrated models, supporting complex environmental database management, allowing relational comparison of territorial information and run the complex simulations associated with a watershed study. QUAL2E, a steadystate model that developed by USEPA (Brown, 1978), and a GIS-linked, semi-distributed modelling framework "SWAT" (Arnold et.al., 1994) were used in this study.

The primary aim of this study is the analysis of the causes determining current trophic conditions in Lake Pusiano through an integrated monitoring and modelling approach, and identify appropriate interventions and management strategies that will allow the sustainable attainment of good water quality.

An initial effort was devoted to understand the effects of actions implemented over the last 15 years on water quality and on the trophic state of the lake. Chemical compounds primarily affecting water quality in Lake Pusiano are nutrients (nitrogen and phosphorus). Until the mid-80's, direct discharges of urban and industrial wastewaters into the River Lambro led to elevate levels of hypertrophy with total phosphorus concentrations up to $200 \mu \mathrm{gP} / 1$. In those years, a sewer network was built, covering $70-80 \%$ of the river watershed, and regulations were implemented to reduce phosphorus. Both factors determined a sensible reduction of nutrient loads into the lake, causing a progressive improvement of the trophic quality of lacustrine waters, evidenced by a reduction of total $\mathrm{P}$ concentrations by approximately $70 \%$ during winter circulation. Currently, the lake still shows eutrophication conditions with total phosphorus concentrations of $69 \mu \mathrm{gP} / 1$ during winter circulation, reduced water transparency and deep layer anoxia during summery stratification. Therefore, the lake is still far from attaining the desired ecological objective. At present, cyanobacteria are dominating the lake's ecosystem (cyanobacterium Planktothrix rubescens was the dominant algal species in Lake Pusiano during 2002). This represents a growing problem both at the national and European levels, as many European lakes underwent a process of oligotrophication, during the last 10-15 years.

Concerning Lake Pusiano trophic status, the attention of this study is therefore focalised on the estimation of nutrient contributions and the analysis of pollution sources, that are not at present 
allowing an improvement of its ecological status. The present situation is caused by nutrient loads that still come from the contributing watershed, through its direct imissaries, as well as through the direct drainage area of the lake. As of today, also several CSOs (Combined Sewer Overflows) are present in the network that drains into the River Lambro, and therefore into Lake Pusiano. It must be considered that the runoff from urban impervious areas represents a diffuse source that can be of relevant intensity, when concerning the urbanised area of Lake Pusiano watershed.

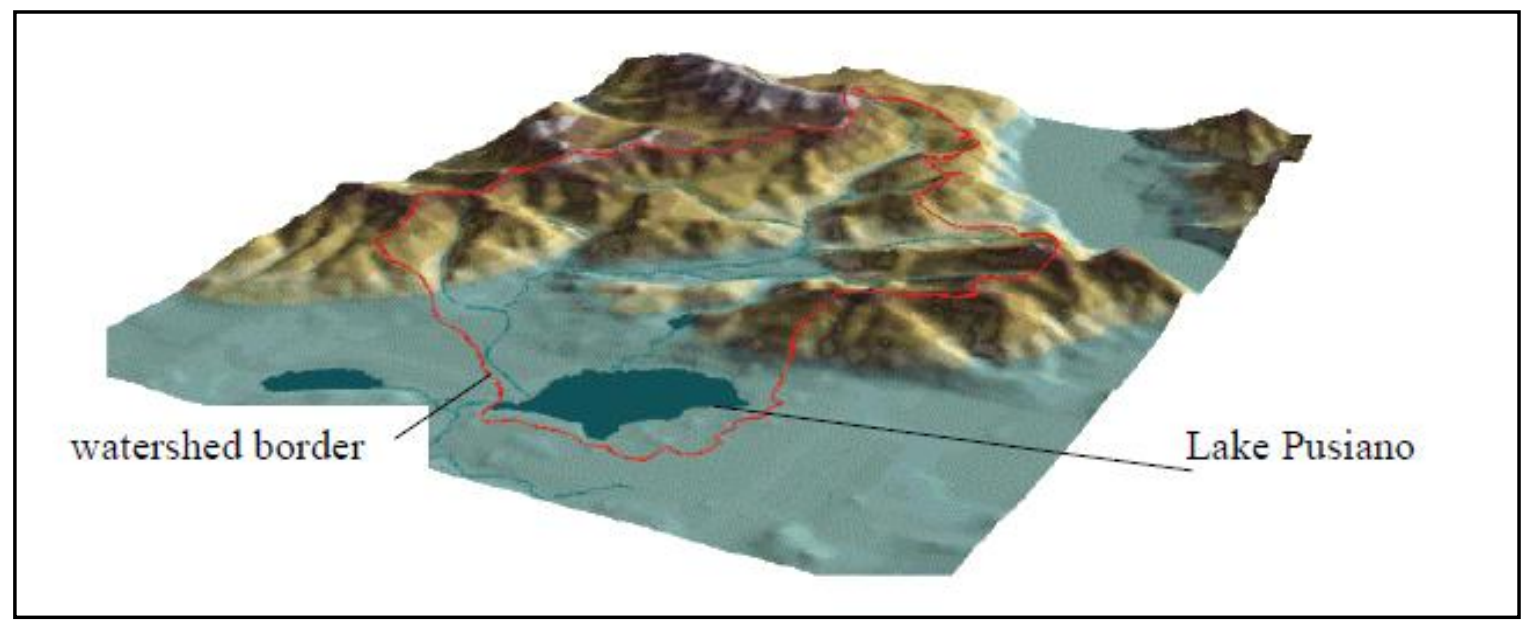

Fig. 1. Digital Terrain Map of the Pusiano Lake Watershed (in the upper right corner the "Lecco brach" of Como Lake is shown)

\section{Site description}

Lake Pusiano is one of the main inter-morenic sub-alpine lakes in the Lombardy region. It is located in the middle of the two branches of Como Lake, with a watershed area of $96.4 \mathrm{~km}^{2}$. The watershed is primarily made of natural (75\%) and urbanised (21\%) territory, while only $4 \%$ of the watershed is agricultural (Figure 2). Forests, mainly deciduous, cover $61 \%$ of the watershed. Land associated with agriculture is primarily corn-cultivated. The major towns in the basin are Erba, Canzo and Pusiano, with a total resident population of about 40000 (Table 1). Average annual rainfall varies between 900 $\mathrm{mm}$ and $1500 \mathrm{~mm}$. Lake Pusiano main immissary is the River Lambro, which water quality is rather poor, mainly due to high nutrient concentrations. The hydrologic system is characterised by a conspicuous underground contribution, and therefore with a hydrogeological watershed that is probably wider than the surface one. In the complex hydrological analysis the geographic position of Lake Pusiano watershed on the southern edge of the Alps must be considered, likely causing significant infiltration phenomena due to the high permeability of the River Lambro alluvial cone.

The current hydrographical system is the result of significant modifications on the River Lambro in proximity of Pusiano, since this reach was channelised in 1811 as a consequence of land reclamation between Erba and Merone. Also the outflows from the lake have been diverted to a gate-regulated artificial channel emissary.

The dominant type of sewerage network in the Lake Pusiano watershed is the combined one: collected runoff from urban areas represents a diffuse source of relevant intensity concerning the watershed's area. Moreover, not all the houses within the basin are served by the sewer network, and not all sewer trunks are connected directly with the main collector. Since 1986, sewage treatment 
plants have been built to serve the area: at the present time these provide secondary treatment for approximately $25400 \mathrm{~m}^{3} /$ day of effluents, however, during wet weather, inflows can often exceed the capacity of the system, thus provoking combined overflow discharges. There are 74 identified CSO's points in the watershed, but little was previously known about their impact on the river environment (Figure 3). Consequently, a study was undertaken to examine baseline chemical conditions in the vicinity of the largest CSOs, and to assess effects that they might have on the river. The majority of CSO's discharge untreated sewage and storm water during rainfall periods (they were designed for a $15 \mathrm{~mm} / 24$ hours rainfall), however, continuous flow also occurs in a few points even during dry weather, due to Infiltration/Inflow water or because of illegal sewage connections, that have been discovered in the examined area in some instances.

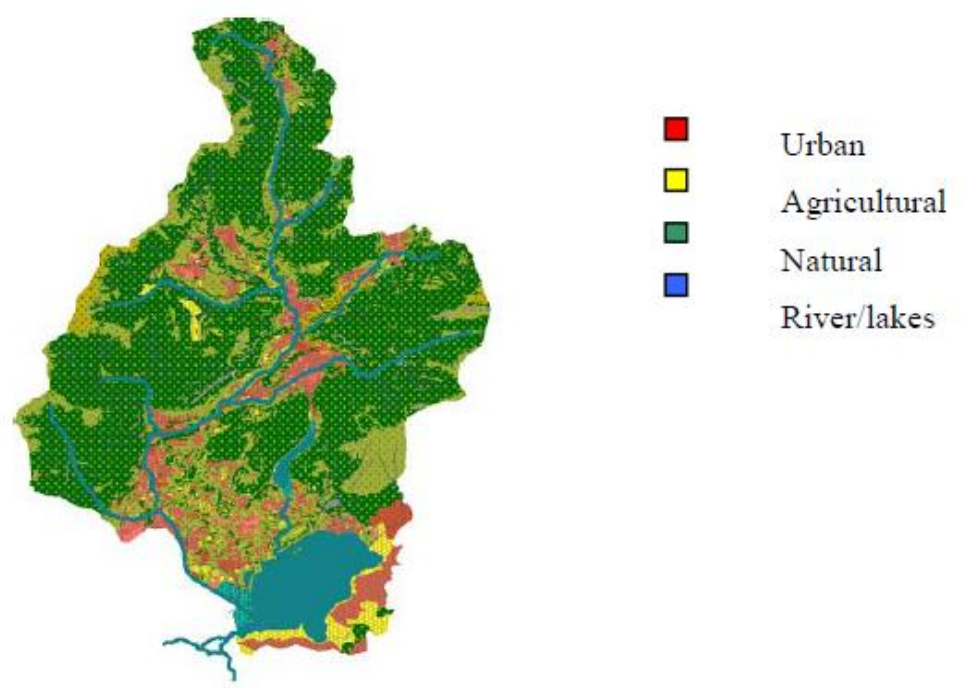

Fig. 2. Land use map of Lake Pusiano watershed

The wastewater treatment plant is located, and discharges, outside the Pusiano watershed and therefore has not been considered in this study. It serves 43 communities with a total population of about 88000 people, and about 40 industries.

Table 1. Resident population in Lake Pusiano watershed

\begin{tabular}{lccc}
\hline Sub-basin & No. residents & $\begin{array}{c}\text { No. residents } \\
\text { not connected }\end{array}$ & $\begin{array}{c}\text { Percentage of } \\
\text { not connected }\end{array}$ \\
\hline Gajum & 23 & 2 & 9 \\
Vallelunga & 53 & 3 & 5 \\
Magreglio & 56 & 44 & 78 \\
Asso & 1624 & 80 & 5 \\
Cavarona & 1114 & 121 & 11 \\
Segrino & 1584 & 195 & 12 \\
Geretta & 5422 & 256 & 5 \\
Lambrone & 8403 & 433 & 5 \\
Foce & 1891 & 558 & 30 \\
Caslino & 9301 & 1050 & 11 \\
Drainage area & 6803 & 720 & 11 \\
\hline Total & $\mathbf{3 6 2 7 4}$ & $\mathbf{3 4 6 2}$ & $\mathbf{9 . 5}$ \\
\hline
\end{tabular}




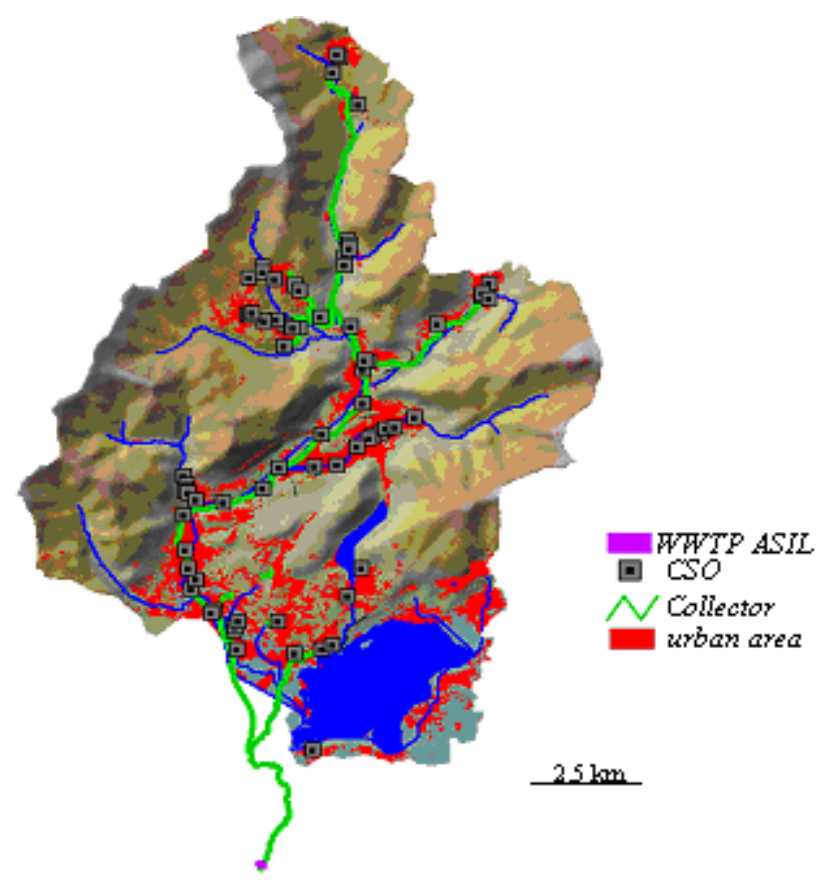

Fig. 3. Identification of CSO's locations

\section{Data analysis}

Since the ' 80 s, monitoring of lake water quality only was performed on a seasonal basis; this sampling program allowed the observation of long -term changes in the lake quality. A new monitoring programme, was implemented since 2002, with the principal aim to measure nutrient loads contributions from the watershed. For this reason, five monitoring points along the main stream of the River Lambro were established. Under PILE, four components of water quality monitoring are carried out:

- Lake monitoring program;

- Sources monitoring program

- River monitoring program (expanded since January 2004)

- CSO monitoring program (since January 2004)

Analysing the data, it was noted that the original five sites sampled since July 2002 did not characterise nutrients from the watershed with sufficient detail, so a new monitoring program was designed and has been applied since January 2004. In order to find suitable measuring points, watershed characteristics were assessed through the use of GIS, linked to natural resource and land-use databases (land-use, land-cover). The GIS was used to "layer" the river basin into different regions, assigning the most common land use/soil type combination to each sub-basin (Figure 4). According to this scheme, main sub-basins were defined as potential sources for nutrient loads. 


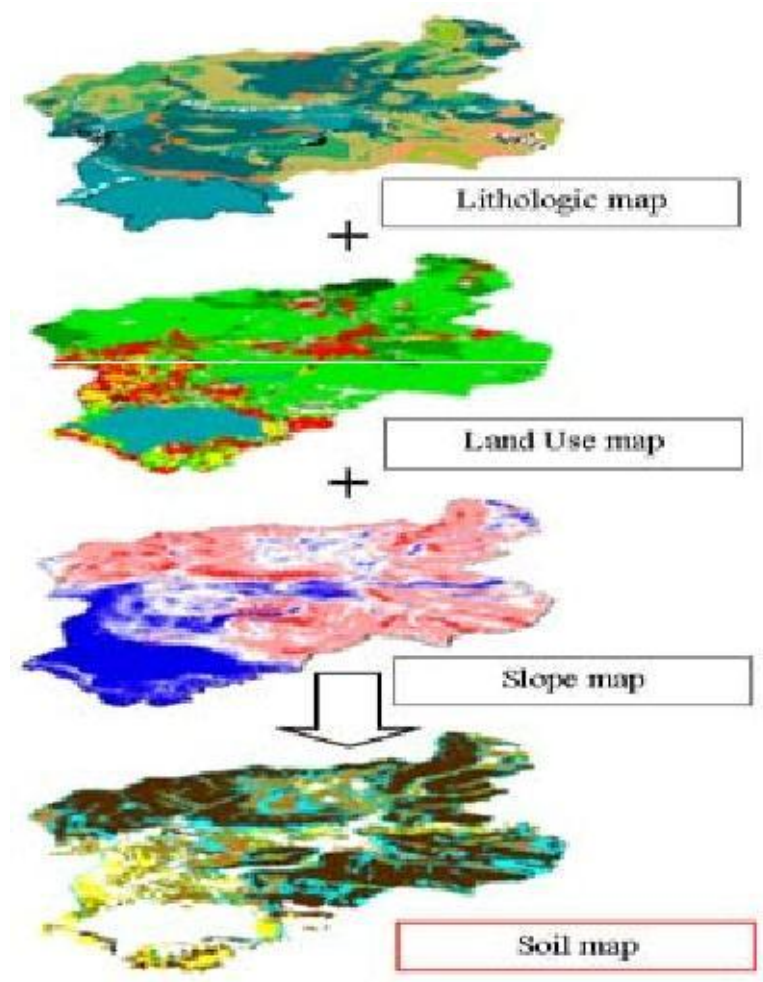

Fig. 4. Basin "layering" for definition of nutrient load sources

\section{A. Analysis of nutrient concentration data}

In the watershed streams, $\mathrm{N}$ is far more plentiful than $\mathrm{P}$, and TN: TP ratios are consistently in the range 40-90:1. Total nitrogen (TN) is dominated by $\mathrm{NO}_{3}{ }^{-}$, whereas $\mathrm{NH}_{4}{ }^{+}$generally increases during high flow events, but consistent annual trend was evident only in the case of ammonium, which loads tend to consistently increase during the fall. In Table 2, a general summary of nutrient values observed in all monitoring stations is presented.

Table 2. Mean $\mathrm{N}$ and $\mathrm{P}$ values for all monitoring stations

\begin{tabular}{|c|c|c|c|c|c|c|c|c|c|c|c|}
\hline $\begin{array}{l}\text { Station } \\
\text { ID }\end{array}$ & Name & $\begin{array}{c}\mathrm{N}^{\mathrm{N} \mathrm{NH}_{4}}{ }^{+} \\
{[\mu \mathrm{gN} / 1]}\end{array}$ & $\begin{array}{l}\text { St. } \\
\text { dev. }\end{array}$ & $\begin{array}{c}\text { Mean } \\
{\mathrm{N}-\mathrm{NO}_{3}}^{-} \\
{[\mathrm{mgN} / \mathrm{l}]}\end{array}$ & $\begin{array}{c}\text { St. } \\
\text { dev. }\end{array}$ & $\begin{array}{c}\text { Mean } \\
\mathrm{TN} \\
{[\mathrm{mgN} / \mathrm{l}]}\end{array}$ & $\begin{array}{l}\text { St. } \\
\text { dev. }\end{array}$ & $\begin{array}{l}\mathrm{P}_{-\mathrm{PO}_{4}}^{3} \\
{[\mu \mathrm{gP} / 1]}\end{array}$ & $\begin{array}{l}\text { St. } \\
\text { dev. }\end{array}$ & $\begin{array}{c}\text { Mean TP } \\
{[\mu \mathrm{gP} / 1]}\end{array}$ & $\begin{array}{l}\text { St. } \\
\text { dev. }\end{array}$ \\
\hline S1 & Magreglio & 49 & 45 & 2.15 & 0.4 & 2.64 & 0.5 & 21 & 22 & 32 & 28 \\
\hline S2 & Asso & 25 & 29 & 2.44 & 0.5 & 2.90 & 0.4 & 24 & 9 & 35 & 26 \\
\hline S3 & Foce & 46 & 86 & 2.47 & 0.6 & 3.03 & 0.5 & 50 & 17 & 80 & 47 \\
\hline S4 & Caslino & 50 & 48 & 2.76 & 0.5 & 3.42 & 0.4 & 20 & 9 & 56 & 97 \\
\hline S5 & Lambrone & 109 & 311 & 3.02 & 0.8 & 3.66 & 0.7 & 26 & 21 & 84 & 115 \\
\hline S6 & $\begin{array}{l}\text { Segrino: } \\
\text { Valle }\end{array}$ & 93 & 219 & 2.35 & 0.8 & 3.15 & 1.0 & 35 & 32 & 78 & 83 \\
\hline M4 & $\begin{array}{l}\text { Segrino: } \\
\text { Monte }\end{array}$ & 79 & 43 & 1.24 & 0.7 & 1.80 & 0.5 & 2 & 2 & 22 & 15 \\
\hline M1 & Cavarona & 15 & 12 & 1.96 & 0.4 & 2.36 & 0.8 & 13 & 7 & 57 & 104 \\
\hline M2 & Gajum & 10 & 7 & 2.68 & 0.2 & 2.83 & 0.3 & 2 & 2 & 11 & 20 \\
\hline M3 & Vallunga & 9 & 4 & 3.66 & 1.3 & 3.68 & 1.1 & 4 & 1 & 16 & 31 \\
\hline S7 & Geretta & 129 & 251 & 3.90 & 1.2 & 4.85 & 1.1 & 63 & 48 & 172 & 201 \\
\hline
\end{tabular}


Inorganic nutrients are generally higher in the downstream reaches of the River Lambro, indicating significant non-point source inputs from the watershed. Nutrients in the tributaries were usually lower except for two sites (Foce, Geretta). Analysis of those tributaries showed instances where high concentrations of total nitrogen and phosphorus were contributed to the watershed. Ammonium concentrations are much higher at Lambrone and Geretta due to CSO loading, rather than from connected houses. Phosphate can be regenerated from sediments in the natural process and can be found in sewage. Combinations of phosphorus generation and summertime nitrogen limitation of phytoplankton productivity were probably responsible for the observed seasonality. Two tributary sites, with heavy nitrogen loading, also received large amounts of orthophosphate: mean levels were $50 \mu \mathrm{g} / 1$ at Foce and $63 \mu \mathrm{g} / \mathrm{l}$ at Geretta. Inputs of inorganic phosphorus from sediments alone cannot account for these levels: runoff has caused phosphate concentrations to exceed $70 \mu \mathrm{g} / 1$ on a few occasions. At Geretta, orthophosphate levels are routinely above $60 \mu \mathrm{g} / 1$ and have surpassed $200 \mu \mathrm{g} / 1$ $(\max 282 \mu \mathrm{g} / \mathrm{l})$. This area appears to be affected by excessive anthropogenic pressure and agricultural loads. On the contrary, Gajum apparently experiences natural loading levels of inorganic phosphorus.

\section{B. CSO nutrient loads}

CSO contaminant concentrations were obtained by sampling five representatives CSOs, selected according to the drainage basin characteristics, which discharge along the River Lambro. Sampling was designed to investigate nutrient concentrations in CSO outfalls and test whether these changed, over the duration of the event, and between CSO's. A specially developed thermistor -analysis technique was developed to determine actual discharge occurrence at outfall and to develop relationships between rainfall intensity and discharge. Monitoring also involved the collection of effluent grab samples for comprehensive chemical analysis. Five storm events were sampled for each representative site (Table 3 ).

For most parameters, CSO discharges from urban-residential areas contained higher levels of $\mathrm{NH}_{4}{ }^{+}$, than those from natural and agricultural ones. Residential and natural areas have very similar $\mathrm{PO}_{4}{ }^{3-}$ concentrations except area 4 with very high $\mathrm{PO}_{4}{ }^{3-}$ concentration. CSO sample sites within forested areas had little to no increases in nitrite plus nitrate concentrations with increasing discharge and virtually no dilution effect. Sample sites within agricultural land use areas show a definite increase in nitrate concentration.

Table 3. Average values of CSO discharge concentrations for all events

\begin{tabular}{lcccccc}
\hline $\begin{array}{l}\text { Quality } \\
\text { parameter* }\end{array}$ & $\begin{array}{c}\text { Forest/ } \\
\text { urban }\end{array}$ & $\begin{array}{c}\text { Forest/ } \\
\text { urban/ } \\
\text { pasture }\end{array}$ & $\begin{array}{c}\text { Forest/ } \\
\text { urban/ } \\
\text { pasture }\end{array}$ & $\begin{array}{c}\text { Urban/ } \\
\text { agriculture }\end{array}$ & Urban \\
\hline $\mathrm{NH}_{4}{ }^{+}$ & {$[\mu \mathrm{g} / \mathrm{l}]$} & 1077 & 976 & 1649 & 2434 & 2796 \\
$\mathrm{NO}_{3}{ }^{-}$ & {$[\mathrm{mg} / \mathrm{l}]$} & 1.70 & 1.34 & 2.54 & 2.54 & 3.74 \\
$\mathrm{TN}^{2}$ & {$[\mathrm{mg} / \mathrm{l}]$} & 3.74 & 3.47 & 4.81 & 6.29 & 8.92 \\
$\mathrm{PO}_{4}{ }^{3-}$ & {$[\mu \mathrm{g} / \mathrm{l}]$} & 115 & 88 & 76 & 514 & 148 \\
$\mathrm{TP}$ & {$[\mu \mathrm{g} / \mathrm{l}]$} & 365 & 304 & 168 & 727 & 768 \\
\hline
\end{tabular}




\section{Integrated Modelling Approach}

Comparison of predicted and observed concentrations of nutrients was performed for the relatively short time period of data available. Analysis for the 2002 to 2004 period in the sections of Lambrone, Geretta and Emissario Segrino show that simulation of TP and TN that enter the lake are accounted for with an underestimation in the order of 9and 5\%, respectively. Considering the complexity of the system and some hydrological difficulties it can be concluded that a good level of approximation was achieved. In this section, results from the SWAT model runs are presented to illustrate how they can be used to evaluate nutrient loadings to Lake Pusiano.

Total phosphorus loads, entering the lake are shown in Figure 5a. The mean influent TP value in those years is about $13 \mathrm{t} / \mathrm{yr}$, however, loads are high variable and strongly dependent on annual hydrological regime. The range of TP load is from $7 \mathrm{t} / \mathrm{yr}$ to $20 \mathrm{t} / \mathrm{yr}$ depending on the amount of precipitation. The mean TN load value, seems to be less variable then that of TP, however, also in this case, dependence on hydrological regime can be observed (Figure 5b).
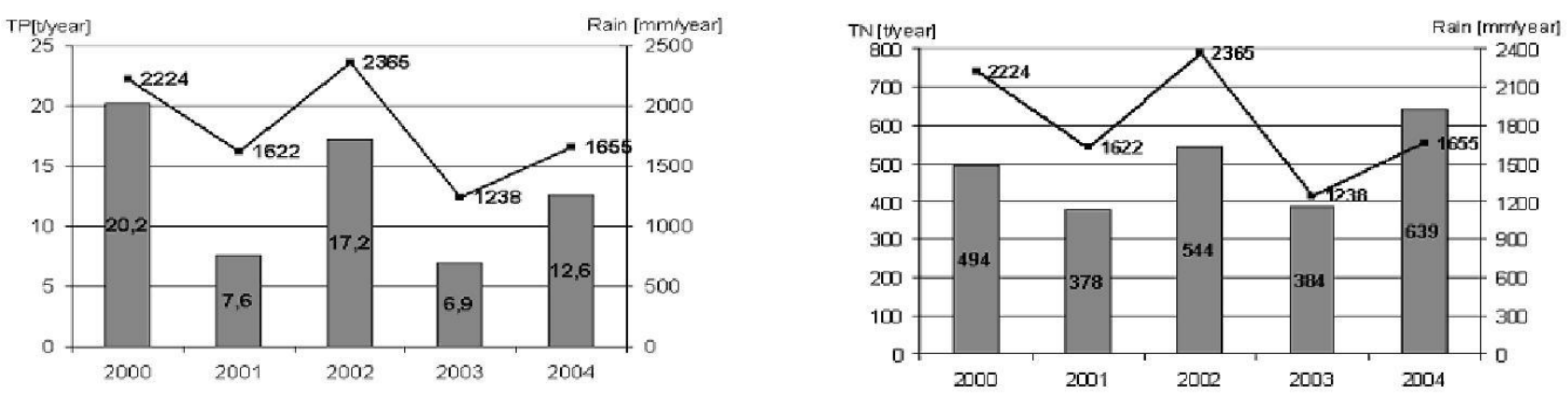

Figure 5. (a) TP loads (left) and (b) TN loads (right) entering Lake Pusiano, simulated with SWAT

The loads in a wet year were more then 2 times those in a dry year in the case of TP, and almost 2 times for TN. This confirms the dynamic nature typical for non- point source loading in most watersheds. This is also likely caused by the different nature and sources of the two nutrients: phosphorus mainly comes from urban and agricultural activities during runoff, while around $50 \%$ of the nitrogen comes, within this sub-alpine area, from atmospheric deposition.

As simulation of phosphorus and nitrogen was available at 10 intermediate sections of the watershed, this allowed the identification of those watershed sub-basins that are mainly responsible for the pollutant loads (Table 4).

Table 4. Simulation of $N$ and $P$ loads at intermediate sections

\begin{tabular}{|c|c|c|c|c|c|c|c|c|}
\hline Sub-basin & $\begin{array}{l}\text { Area } \\
{\left[\mathrm{km}^{2}\right]} \\
\end{array}$ & $\begin{array}{c}\text { Mean } \\
\text { flow } \\
{\left[\mathrm{m}^{3} / \mathrm{s}\right]}\end{array}$ & $\begin{array}{c}\mathrm{TP} \\
{[\mathrm{t} / \mathrm{yr}]} \\
\end{array}$ & ТP \% & $\begin{array}{c}\mathrm{TP} \\
\text { yield } \\
{\left[\mathrm{t} / \mathrm{km}^{2}\right]} \\
\end{array}$ & $\mathrm{TN}[\mathrm{t} / \mathrm{yr}]$ & $\mathrm{TN} \%$ & $\begin{array}{l}\text { TN yield } \\
{\left[\mathrm{t} / \mathrm{km}^{2}\right]}\end{array}$ \\
\hline Magreglio & 1.4 & 0.05 & 0.2 & 1 & 0.14 & 5.2 & 1 & 3.72 \\
\hline Asso & 13.5 & 0.19 & 0.8 & 6 & 0.06 & 28.9 & 6 & 2.14 \\
\hline Caslino & 13 & 0.98 & 2.8 & 22 & 0.22 & 181.5 & 37 & 13.96 \\
\hline Cavarona & 12.2 & 0.46 & 0.9 & 7 & 0.07 & 17.2 & 4 & 1.41 \\
\hline Foce & 7.8 & 0.19 & 0.6 & 5 & 0.08 & 25.6 & 5 & 3.28 \\
\hline
\end{tabular}




\begin{tabular}{|c|c|c|c|c|c|c|c|c|}
\hline Gajum & 5.4 & 0.14 & 0.1 & 0 & 0.02 & 4.6 & 1 & 0.86 \\
\hline Vallunga & 9.7 & 0.27 & 0.4 & 3 & 0.04 & 11.3 & 2 & 1.17 \\
\hline \multirow[t]{2}{*}{ Lambrone } & 7.5 & 0.26 & 1.7 & 13 & 0.23 & 128.1 & 26 & 17.09 \\
\hline & 70.5 & 2.55 & 7.5 & & 0.85 & 402.5 & & 43. \\
\hline Infiltration & & -1.07 & & & & & & \\
\hline Lambrone & 70.5 & 1.48 & 6.5 & 52 & 0.09 & 358.9 & 81 & 5.09 \\
\hline Segrino & 4.7 & 0.25 & 0.7 & 5 & 0.15 & 19.4 & 4 & 4.14 \\
\hline Geretta & 4.4 & 0.26 & 2.7 & 21 & 0.61 & 48.0 & 11 & 10 . \\
\hline $\begin{array}{l}\text { Direct } \\
\text { watershed }\end{array}$ & 10.1 & 0.19 & 2.7 & 22 & 0.27 & 18.0 & 4 & \\
\hline total & 89.7 & & 12.6 & 100 & 0.14 & 444.3 & 100 & \\
\hline
\end{tabular}

\section{Sustainable water quality management}

In developing loads assessment, one must take into account the "critical condition" for stream flow, loads, and water quality parameters. The "critical condition" is generally defined as the condition in which physical, chemical, and biological characteristics of the receiving water environment interact with the effluent to produce the greatest potential adverse impact on aquatic biota and existing, or characteristic, water uses. Critical conditions are important because they describe the factors that, when combined, would cause a violation of water quality standards. The intent of this requirement is to ensure that the water quality of the receiving water body is protected during times, when it is most vulnerable.

Critical condition in Lake Pusiano is high flow, when nutrient contributions are dominated by nonpoint sources or CSO discharges. High-flow conditions downstream of Lambrone are perceived to be dominated by runoff and CSO sources contributions, while base flow with background nutrient concentrations is likely controlled by groundwater. However, background contributions are much smaller in comparison to non-point source contributions during high-flow conditions.

Analysis of N:P ratios in the Lake since 1991 shows that phosphorus is the limiting nutrient, however, the variation of the $\mathrm{N}: \mathrm{P}$ ratio may have important effects on the composition of algal assemblages in the recipient ecosystems, especially with regards to the mentioned cyanobacteria dominance. A phosphorus concentration criterion was evaluated for Lake Pusiano, using different approaches, as $19.5 \mathrm{mg} / \mathrm{m}^{3}$ in order to reach "natural" conditions. Using historical data, a concentration between $20 \mathrm{mg} / \mathrm{m}^{3}$ and $35 \mathrm{mg} / \mathrm{m}^{3}$ is, on the other hand, consistent with restoring the lake's nutrient status to the least impacted condition that has been observed.

Main sources of TP are concentrated around the lake's direct drainage area, Geretta and Caslino representing almost $70 \%$ of the loads. Between these, Geretta contributes three times the TP than the other. Results show that $87 \%$ of TP loads that enter Lake Pusiano are of anthropic origin: precipitation events contribute about $8.5 \mathrm{t} / \mathrm{yr}$ of TP, and $2.4 \mathrm{t} / \mathrm{yr}$ come from population not connected to the sewer network

Based on the predicted values and analyses, the principles for sustainable management in the basin could be set as follows: reduce loads from the Geretta channel. It is proposed to alter the course of the channel, avoiding its direct contribution into the lake. From the hydrological point of view the modification is negligible (on average $0.23 \mathrm{~m}^{3} / \mathrm{s}$ corresponding to $8 \%$ of the lake inflows). This action will reduce loads of $2.7 \mathrm{t} / \mathrm{yr}$. 
A second action would be the completion of sewer network connections, concentrating efforts to the high-urbanized areas. This would allow reduction of 1.6 ton of TP.

A third action would focus on CSO's, eliminating loads using exiting storage capacity or collect only rainfall water. Thic could account for reduction of $1.6 \mathrm{t} / \mathrm{yr} \mathrm{TP}$.

A fourth action considers controls placed on the amount of impervious areas as well as on stormwater systems with pre-detention basins in the lake immediate drainage area. The creation of vegetated strips can be another solution, having been proved that even small riparian vegetated buffers can reduce nutrients flux to streams, and forested buffers in agricultural watersheds seem more effective. The reduction by half or a third of the area loads $(1.0-0.7 \mathrm{t} / \mathrm{yr})$ could be reached this way. Combination of those actions would allow reducing $6.6 \mathrm{t} / \mathrm{yr}$ TP loads, and therefore would allow approach to the mesotrophic objective for Lake Pusiano.

\section{References}

ASCE: American Society of Civil Engineers (1993). Criteria for Evaluation of Watershed Models. Journal of Irrigation and Drainage Engineering 119(3): 429-442, ISSN 0733-9437.

ASIL (1998). Report of activity. Consorzio ecologico dell'alto Lambro e Piano d'Erba.

ASIL (2003). Report. Interventi di collettamento e depurazione stato di fatto e previsioni. Consorzio Ecologico dell'Alto Lambro e piano d'Erba.

Balestrini, R., L. Galli and G. Tartari. (2000). Wet and dry atmospheric deposition at prealpine and alpine sites in Northern Italy. Atmospheric Environment, 34: 1455-1470.

Barnwell Jr.; Linfield C. Brown; and Raymond C. Whittemore. (2003). Importance of Field Data in Stream Water Quality Modeling Using QUAL2E-UNCAS. Journal of Environmental Engineering, Vol. 130, No. 6, June 1, 2003.

Salerno, F., Boguniewicz J., Buraschi E., Vuillermoz E., Tartari. G. (2004). Application of a semidistributed model to a complex hydrogeological watershed. Proceedings ECO-GEOWATER EuroWorkshop "GI for International River Basin Management", Budapest, June 3-5, 2004.

Vanrolleghem P., Schilling W., Rauch W., Krebs P. and Aalderink H. (1999). Setting up Measuring Campaigns for Integrated Wastewater Modelling, Wat. Sci. Tech. 39(4), 257-268. 